Article

\title{
Fatty Acid and Phytosterol Content of Commercial Saw Palmetto Supplements
}

\author{
Kavitha Penugonda and Brian L. Lindshield * \\ Department of Human Nutrition, Kansas State University, Manhattan, KS 66506, USA; \\ E-Mail: kavithap@k-state.edu \\ * Author to whom correspondence should be addressed; E-Mail: blindsh@k-state.edu; \\ Tel.: +1-785-532-7848; Fax: +1-785-532-3132.
}

Received: 13 June 2013; in revised form: 16 August 2013 / Accepted: 20 August 2013 /

Published: 13 September 2013

\begin{abstract}
Saw palmetto supplements are one of the most commonly consumed supplements by men with prostate cancer and/or benign prostatic hyperplasia (BPH). Some studies have found significant improvements in BPH and lower urinary tract symptoms (LUTS) with saw palmetto supplementation, whereas others found no benefits. The variation in the efficacy in these trials may be a result of differences in the putative active components, fatty acids and phytosterols, of the saw palmetto supplements. To this end, we quantified the major fatty acids (laurate, myristate, palmitate, stearate, oleate, linoleate) and phytosterols (campesterol, stigmasterol, $\beta$-sitosterol) in 20 commercially available saw palmetto supplements using GC-FID and GC-MS, respectively. Samples were classified into liquids, powders, dried berries, and tinctures. Liquid saw palmetto supplements contained significantly higher $(p<0.05)$ concentrations of total fatty acids $(908.5 \mathrm{mg} / \mathrm{g})$, individual fatty acids, total phytosterols $(2.04 \mathrm{mg} / \mathrm{g})$, and individual phytosterols, than the other supplement categories. Powders contained significantly higher $(p<0.05)$ concentrations of total fatty acids than tinctures, which contain negligible amounts of fatty acids $(46.3 \mathrm{mg} / \mathrm{g})$ and phytosterols $(0.10 \mathrm{mg} / \mathrm{g})$. Our findings suggest that liquid saw palmetto supplements may be the best choice for individuals who want to take a saw palmetto supplement with the highest concentrations of both fatty acids and phytosterols.
\end{abstract}

Keywords: saw palmetto; serenoa repens; prostate; benign prostatic hyperplasia; prostate cancer; fatty acids; phytosterols; supplements 


\section{Introduction}

Saw palmetto (Serenoa repens) herbal supplements are commonly used by men to combat benign prostatic hyperplasia (BPH), a nonmalignant enlargement of the prostate. In addition to BPH, these supplements are commonly consumed by men diagnosed with prostate cancer. In 2007, 5.1\% ( $\sim 1.7$ million people) of Americans 18 years of age or older reported using saw palmetto in the past 30 days [1]. In 2011, over $\$ 18$ million in saw palmetto was sold in the United States, ranking third among herbal dietary supplements [2]. A systematic literature review of 11 studies identified saw palmetto supplements as one of five commonly used complementary or alternative medicine modalities by men with prostate cancer; use was $1.9 \%-24.9 \%$ [3]. Another study found that $13.8 \%$ of unaffected men whose brothers had been diagnosed with prostate cancer had taken saw palmetto at some point in their lives [4].

Saw palmetto's putative mechanism of action is inhibition of $5 \alpha$-reductase, the enzyme that converts testosterone into the more potent androgen dihydrotestoterone [5-10]. Studies that have found saw palmetto administration or treatment reduced androgen action support this belief [11-15]; however, not all studies have found that saw palmetto inhibits 5 $\alpha$-reductase or has anti-androgen action [16-18]. The believed bioactive components of saw palmetto are fatty acids and phytosterols. Saw palmetto extracts predominantly consist of fatty acids $(\sim 90 \%)$ and are unique compared with other extracts and vegetable and nut oils [19] in that they are a rich source of the saturated, medium-chain fatty acids laurate (12:0) and myristate (14:0) [20].

Several studies suggest that the fatty acids in saw palmetto extracts are responsible for its ability to inhibit 5a-reductase [21-26], but which fatty acid(s) is/are responsible for the inhibition varies. Some research suggests that saw palmetto phytosterols ( $\beta$-sitosterol, campesterol, stigmasterol), inhibit $5 \alpha$-reductase, prostate cancer cell/tumor growth, and/or BPH symptoms [27-31]; however, these phytosterols are not unique to saw palmetto extracts [32]. Nevertheless, a combination of fatty acids, phytosterols, and other bioactive components may be responsible for beneficial effects reported from saw palmetto supplements.

Saw palmetto extract decreased testosterone-induced prostate hyperplasia [15] in rats and prostate cancer progression in TRAMP mice [14]. A number of studies have found that saw palmetto supplements improve lower urinary tract symptoms (LUTS) in men suffering from BPH. The two largest, highest-quality BPH clinical trials [33,34], however, failed to find a benefit of supplementation, leading a systematic literature review to conclude that saw palmetto supplementation provides no benefit [35].

Although methodological issues or distinctions may be responsible for these conflicting findings, it is also possible that differences in the nutrient profiles of the saw palmetto supplements used in the studies influenced the results. In support of this possibility, different saw palmetto supplements exhibited varied effectiveness in inhibiting 5 $\alpha$-reductase activity and prostate cancer cell proliferation [36,37]. In addition, Wolsko et al. found that only 6/26 (26\%) of published saw palmetto randomized-controlled trials reported performing quantitative analysis on the extract used [38]. This is important because the fatty acid content of saw palmetto supplements has been found to be $-97 \%$ to $+140 \%$ of stated dosages [39], and a separate study found that supplements mean free fatty acid percentages ranged from $40.7 \%$ to $80.7 \%$ [40]. 
Others have also measured fatty acid [15,20,41-43] or phytosterol content [42,44,45] of saw palmetto, but despite the reported differences in saw palmetto supplement contents, to the best of our knowledge, no one has characterized both the fatty acid and phytosterol contents of commercially available supplements or compared different supplement categories. Thus, we set out to characterize these saw palmetto supplement components, hypothesizing that we would find large differences in their quantities and composition.

\section{Materials and Methods}

\subsection{Sample Procurement}

Twenty commercially available saw palmetto supplements were procured from online and local sources. Standard reference material (SRM) 3251, a Serenoa repens extract, was purchased from the National Institute of Standards and Technology (NIST; Gaithersurg, MD, USA) to ensure the accuracy of the fatty acid and phytosterol analysis [20]. Supplements were classified into the following categories based on their physical properties: (1) liquids, (2) powders, (3) dried berries, and (4) tinctures (Table 1).

\subsection{Sample Preparation}

Representative samples from each category were prepared as follows. For liquids, 4-5 gel capsules were emptied into a microcentrifuge tube and gently vortexed. For powders, 4-5 powder capsules were emptied into a weigh boat and the contents were mixed thoroughly with a spatula to break up any lumps; tablets were ground to smooth powder using a mortar and pestle. Dried berries were ground using a coffee grinder until they reached a coarse powder texture. Tincture bottles were vortexed before taking a sample. SRM ampoules were vortexed and the contents were transferred to microcentifuge tubes. Samples, and SRM, were extracted and analyzed in duplicate. Care was taken to select the duplicates from the same lot number. All materials were from Fisher Scientific (Pittsburgh, PA, USA) unless noted.

\subsection{Fatty Acid Extraction and Transesterification}

Fatty acids were prepared for analysis using the one-step extraction-transesterification method [46]. Approximately $40 \mathrm{mg}$ of SRM, $40 \mathrm{mg}$ of liquid supplements, $150 \mathrm{mg}$ of powder supplements, $150 \mathrm{mg}$ of dried berry powder, or $250 \mathrm{mg}$ of tinctures were placed into $15 \mathrm{~mL}$ tubes with Teflon-lined screw caps. These amounts were selected because they were estimated to contain $\sim 10-50 \mathrm{mg}$ of total fatty acids based on label information. Two milliliters of benzene containing $2 \mathrm{mg}$ of the internal standard methyl tridecanoate (Sigma-Aldrich, St. Louis, MO, USA) and $3 \mathrm{~mL}$ of freshly prepared methanolic-HCl were added. The tubes were capped, vortexed, and incubated at $70{ }^{\circ} \mathrm{C}$ for $2 \mathrm{~h}$ in a water bath. After allowing them to cool to room temperature, $5 \mathrm{~mL}$ of $6 \%$ potassium carbonate and $2 \mathrm{~mL}$ of benzene were added, and the tubes were vortexed and centrifuged at $500 \times g$ for $5 \mathrm{~min}$. The supernatant was carefully transferred to vials for analysis. 
Table 1. Saw palmetto supplements' names, manufacturing locations, and other label ingredients.

\begin{tabular}{|c|c|c|}
\hline Saw Palmetto Supplement & Other Label Ingredients & Lot Number \\
\hline \multicolumn{3}{|l|}{ Liquids } \\
\hline Doctor's Best (San Clemente, CA, USA) & Gelatin, glycerin, water & 9I1215 \\
\hline GNC Herbal Plus (Pittsburgh, PA, USA) & $\begin{array}{l}\text { Olive oil, gelatin, glycerin, caramel } \\
\text { color, titanium dioxide }\end{array}$ & NI \\
\hline Spring Valley Natural Foods (Springfield, MO, USA) & Olive oil, gelatin, glycerin, water & 36994690904 \\
\hline Now Foods (Bloomingdale, IL, USA) & Extra virgin olive oil, gelatin, glycerin & 11676001159 \\
\hline Solaray (Park City, UT, USA) & Extra virgin olive oil, gelatin, glycerin & 132812 \\
\hline $\begin{array}{l}\text { Saw Palmetto Harvesting Company } \\
\text { (Lengby, MN, USA) }\end{array}$ & NI & NI \\
\hline Jarrow Formulas (Los Angeles, CA, USA) & $\begin{array}{l}\text { Pumpkin seed oil, vitamin E, gelatin, } \\
\text { glycerin, water }\end{array}$ & 43044J9 \\
\hline \multicolumn{3}{|l|}{$\begin{aligned} \text { Powders } & \end{aligned}$} \\
\hline $\begin{array}{l}\text { Permixon (Pierre Fabre Medicament, } \\
\text { Boulogne Cedex, France) }\end{array}$ & NI & G06167 \\
\hline Biochem (Country Life, Hauppauge, NY, USA) & $\begin{array}{l}\text { Pygeum extract, magnesium stearate, } \\
\text { calcium silicate, magnesium silicate, } \\
\text { silica, cellulose }\end{array}$ & 09G802C \\
\hline Natures' Way Products, Inc. (Springville, UT, USA) & Magnesium stearate, gelatin, glycerin & 585612 \\
\hline Solaray (Park City, UT, USA) & Vegetable cellulose capsule & 140401 \\
\hline GNC Saw Palmetto Formula (Pittsburgh, PA, USA) & $\begin{array}{l}\text { Pumpkin seed meal powder, pygeum } \\
\text { bark powder, lycopene, zinc, } \\
\text { cellulose, dicalcium phosphate, } \\
\text { povidone }\end{array}$ & $5795 \mathrm{KJ} 3613$ \\
\hline \multicolumn{3}{|l|}{ Dried Berries } \\
\hline $\begin{array}{c}\text { Mountain Rose Herbs } \\
\text { (Dried Berries, Eugene, OR, USA) }\end{array}$ & None & 9498 \\
\hline $\begin{array}{c}\text { Mountain Rose Herbs } \\
\text { (Powdered Berries, Eugene, OR, USA) }\end{array}$ & None & 9646 \\
\hline $\begin{array}{c}\text { More than alive } \\
\text { (Powdered Berries, Lobelville, TN, USA) }\end{array}$ & None & NI \\
\hline \multicolumn{3}{|l|}{ Tinctures } \\
\hline Oregon’s Wild Harvest (Sandy, OR, USA) & Organic alcohol, water & SB12159E01 \\
\hline GAIA Herbs, Inc. (Brevard, NC, USA) & Grain alcohol & 6212054600 \\
\hline LA Naturals (Michigan City, IN, USA) & $\begin{array}{l}\text { Grain alcohol } 70 \%-80 \%, \\
\text { deionized water }\end{array}$ & 7R44ALL \\
\hline Teeter Creek Herbs (Ava, MO, USA) & $\begin{array}{l}\text { Grain alcohol } 40 \%-50 \% \\
\text { distilled water }\end{array}$ & NI \\
\hline Nature's Answer (Hauppauge, NY, USA) & $\begin{array}{l}\text { Vegetable glycerin, purified United } \\
\text { States Pharmacopeia (USP) water }\end{array}$ & 092469 \\
\hline
\end{tabular}

NI: no information on the label.

\subsection{Fatty Acid Methyl Esters (FAMEs) Gas Chromatography-Flame Ionization Detector (GC-FID) Analysis}

Sample extracts were analyzed for fatty acid methyl esters using a Hewlett-Packard model 5890 GC (Hewlett-Packard, Palo Alto, CA, USA) with a SP-2560 capillary column $\left(100 \mathrm{~m} \times 0.25 \mathrm{~mm} \times d_{\mathrm{f}}\right.$ 
$0.2 \mu \mathrm{m}$, Supelco, Inc., Bellefonte, PA, USA). Injection port and detector temperatures were maintained at $250{ }^{\circ} \mathrm{C}$. Helium was used as the carrier gas at a flow rate of $1 \mathrm{~mL} / \mathrm{min}$. One microliter of sample was injected at a split ratio of 100:1. A temperature gradient was used with an initial oven temperature of $140{ }^{\circ} \mathrm{C}$ that increased to $200{ }^{\circ} \mathrm{C}$ at $2{ }^{\circ} \mathrm{C} / \mathrm{min}$, then to $245{ }^{\circ} \mathrm{C}$ at $4{ }^{\circ} \mathrm{C} / \mathrm{min}$, and the sample held at this temperature for $17 \mathrm{~min}$. The total run time was $66 \mathrm{~min}$. Fatty acid methyl esters (FAMEs) were identified by their retention times using the FAME standard mix (Supelco, Bellefonte, PA, USA) and quantified using Agilent ChemStation software [47]. Thirty-seven fatty acids were analyzed and quantified and contributed to the total fatty acid results reported, but only the six major fatty acids, laurate $(\mathrm{C} 12: 0)$, myristate $(\mathrm{C} 14: 0)$, palmitate $(\mathrm{C} 16: 0)$, stearate $(\mathrm{C} 18: 0)$, oleate $(\mathrm{C} 18: 1)$, and linoleate (C18:2), are reported individually. The mean percent coefficient of variance between duplicates for total fatty acids was $0.8 \%$.

\subsection{Phytosterol Extraction}

Phytosterols were extracted using a method described previously with modifications [48]. Approximately $100 \mathrm{mg}$ of SRM, liquid, powder, and dried berry supplements and $1000 \mathrm{mg}$ of tincture supplements were weighed into separate $250 \mathrm{~mL}$ Erlenmeyer flasks. Forty milliliters of $0.3 \mathrm{M}$ potassium hydroxide in methanol and $10 \mu \mathrm{L}(1 \mathrm{mg} / \mathrm{mL}$ chloroform) of cholestanol (Steraloids, Inc., Newport, RI, USA) were added to each flask. The extracts were distilled at $80{ }^{\circ} \mathrm{C}$ using a condenser for $1 \mathrm{~h}$ with continuous stirring. After cooling the flasks to room temperature, $40 \mathrm{~mL}$ of double-distilled water was added. Twenty milliliters of hexane was then added, and the contents were transferred to a separatory funnel. The separatory funnel was carefully inverted, gently rotated, then allowed to stand for 5-10 min. The bottom white turbid aqueous layer was discarded retaining the clear upper hexane layer. The contents of the separatory funnel were then extracted by adding $20 \mathrm{~mL}$ of hexane twice. The clear hexane layers were collected and filtered through a glass funnel containing glass wool and sodium sulfate. Filtered hexane extracts were concentrated using a Brinkmann Buchi Rotavapor R110 (Buchi, Switzerland) at $50{ }^{\circ} \mathrm{C}$, transferred to test tubes, then evaporated to dryness under nitrogen. The dried contents were redissolved in $1 \mathrm{~mL}$ of chloroform and stored at $-80{ }^{\circ} \mathrm{C}$ for derivatization.

\subsection{Phytosterol Derivatization}

Phytosterols were derivitaized and analyzed by gas chromatography-mass spectrometry as described previously with modifications [49]. Two hundred microliters of extracted sample was used for derivatization. A smaller volume was used for samples that contained high levels of phytosterols. Samples were placed in $1.5 \mathrm{~mL}$ screw-cap GC vials (Agilent, Santa Clara, CA, USA), dried completely under nitrogen, and redissolved in $70 \mu \mathrm{L}$ pyridine $(99.5 \%$ extra dry with AcroSeal, Acros Organics, Geel, Belgium) for derivatization. The samples in pyridine were derivatized by adding $30 \mu \mathrm{L}$ of $N$-trimethylsilyl- $N$-methyltrifluoroacetamide with $1 \%$ trimethylchlorosilane (MSTA $+1 \%$ TMCS Thermo Scientific, Bellefonte, PA, USA) and incubated at $50{ }^{\circ} \mathrm{C}$ for $60 \mathrm{~min}$ on a hot plate. Derivatized samples were completely dried down under nitrogen, redissolved in $100 \mu \mathrm{L}$ of chloroform, and analyzed within $24 \mathrm{~h}$ of derivatization. 


\subsection{Phytosterol Gas Chromatography-Mass Spectrometry (GC-MS)}

GC-MS was performed on an Agilent 6890N GC coupled to an Agilent 5975N quadruple mass selective detector. The GC was fitted with a DB-5MS capillary column $\left(60 \mathrm{~m} \times 0.25 \mathrm{~mm} \times d_{\mathrm{f}}\right.$ $0.25 \mu \mathrm{m}$, Agilent Technologies, Santa Clara, CA, USA) with a 5\% phenyl methyl siloxane stationary phase. Helium was used as the carrier gas at a column flow rate of $1 \mathrm{~mL} / \mathrm{min}$. The front inlet was operating at a pressure of $22.33 \mathrm{psi}$ and $280^{\circ} \mathrm{C}$. An Agilent 7683 autosampler was used to inject $1 \mu \mathrm{L}$ of the sample in the splitless mode. The $\mathrm{GC}$ temperature program was: initial temperature of $80{ }^{\circ} \mathrm{C}$, increased $25^{\circ} \mathrm{C} / \mathrm{min}$ to $300{ }^{\circ} \mathrm{C}$, then increased $3{ }^{\circ} \mathrm{C} / \mathrm{min}$ to a final temperature of $325^{\circ} \mathrm{C}$, where it was held for $7 \mathrm{~min}$. The total run time was $24.5 \mathrm{~min}$. The mass spectrometer was operated in the electron impact (EI) mode at $70 \mathrm{eV}$ ionization energy. The MS quad temperature was at $150{ }^{\circ} \mathrm{C}$, and the MS source temperature was at $230{ }^{\circ} \mathrm{C}$. The data were processed with Agilent Chemstation. The three major phytosterols campesterol, stigmasterol, $\beta$-sitosterol, were quantified and summed to calculate total phytosterol content. The mean percent coefficient of variance between replicates for total phytosterol was $10.8 \%$.

\subsection{Statistical Analysis}

Data were analyzed using SAS 9.3 (SAS Institute Inc., Cary, NC, USA), with $p<0.05$ considered significant. Natural logs were used to transform data that did not meet the assumptions of normality and/or homogeneity of variance. Differences in individual fatty acid and phytosterol quantities and percentages, total fatty acid and phytosterol quantities, and percentages among the four supplement categories were analyzed using one-way ANOVA with Tukey's test. The variation between duplicates was assessed by dividing the standard deviation with duplicate mean and multiplying with 100 to calculate the mean percent coefficient of variation.

\section{Results}

\subsection{Fatty Acid Quantities and Percentages between Supplement Categories}

Fatty acid quantities and percentages of the SRM, liquid, powder, dried berry, and tincture saw palmetto supplements are shown in Tables 2 and 3. Nature's Answer was not included in the tincture means and was excluded from statistical analysis due to its negligible fatty acid content $(0.1 \mathrm{mg} / \mathrm{g})$. Oleate and laurate were the predominant fatty acids across the different supplement categories. Liquid supplements contained significantly higher quantities of total $(908.5 \mathrm{mg} / \mathrm{g})$ and individual fatty acids than powder, dried berry, and tincture supplements. Liquid supplements contained significantly higher percentages of oleate and total fatty acids and significantly lower percentages of laurate and myristate than the other supplement categories. The total fatty acid content of powder supplements $(179.6 \mathrm{mg} / \mathrm{g})$ was similar to dried berry $(126.4 \mathrm{mg} / \mathrm{g})$ but significantly higher than tincture supplements $(46.3 \mathrm{mg} / \mathrm{g})$. Powder supplements contained significantly higher quantities of palmitate and stearate than dried berries and tinctures and significantly higher quantities of linoleate and total fatty acids than dried berries. Powder supplements contained significantly higher palmitate and stearate percentages than the other supplement categories, and tinctures contained significantly higher percentages of laurate than liquid and powder supplements. 
Table 2. Fatty acid quantities ( $\mathrm{mg} / \mathrm{g}$ ) and composition (\% of total fatty acids) in SRM, liquid, and powder saw palmetto supplements.

\begin{tabular}{|c|c|c|c|c|c|c|c|c|c|c|c|c|c|c|}
\hline \multirow[t]{2}{*}{ Supplement } & \multicolumn{2}{|c|}{$\begin{array}{l}\text { Laurate } \\
\text { (C12:0) }\end{array}$} & \multicolumn{2}{|c|}{$\begin{array}{c}\text { Myristate } \\
\text { (C14:0) }\end{array}$} & \multicolumn{2}{|c|}{$\begin{array}{l}\text { Palmitate } \\
\text { (C16:0) }\end{array}$} & \multicolumn{2}{|c|}{$\begin{array}{l}\text { Stearate } \\
\text { (C18:0) }\end{array}$} & \multicolumn{2}{|c|}{$\begin{array}{l}\text { Oleate } \\
\text { (C18:1) }\end{array}$} & \multicolumn{2}{|c|}{$\begin{array}{c}\text { Linoleate } \\
\text { (C18:2) }\end{array}$} & \multicolumn{2}{|c|}{$\begin{array}{c}\text { Total Fatty } \\
\text { Acid }\end{array}$} \\
\hline & $\mathrm{mg} / \mathrm{g}$ & $\%$ & $\mathrm{mg} / \mathrm{g}$ & $\%$ & $\mathrm{mg} / \mathrm{g}$ & $\%$ & $\mathrm{mg} / \mathrm{g}$ & $\%$ & $\mathrm{mg} / \mathrm{g}$ & $\%$ & $\mathrm{mg} / \mathrm{g}$ & $\%$ & $\mathrm{mg} / \mathrm{g}$ & $\% *$ \\
\hline \multicolumn{15}{|c|}{ Liquid Extracts $(n=7)$} \\
\hline Doctor's Best & 276.6 & 29.4 & 105.4 & 11.2 & 86.9 & 9.2 & 17.5 & 1.9 & 313.9 & 33.4 & 43.6 & 4.6 & 941.3 & 94.1 \\
\hline GNC Herbal Plus & 82.9 & 8.9 & 33.8 & 3.6 & 94.0 & 10.1 & 25.4 & 2.7 & 582.3 & 62.4 & 59.1 & 6.3 & 933.8 & 93.4 \\
\hline Spring Valley Natural Foods & 170.3 & 18.5 & 67.6 & 7.3 & 85.8 & 9.3 & 24.1 & 2.6 & 448.5 & 48.6 & 53.9 & 5.8 & 923.4 & 92.3 \\
\hline Now Foods & 141.6 & 15.5 & 51.6 & 5.7 & 107.0 & 11.7 & 21.1 & 2.3 & 438.1 & 47.9 & 81.0 & 8.9 & 914.7 & 91.5 \\
\hline Solaray & 141.9 & 15.6 & 57.1 & 6.3 & 90.9 & 10.0 & 21.2 & 2.3 & 476.0 & 52.1 & 55.6 & 6.1 & 913.0 & 91.3 \\
\hline Saw Palmetto Harvesting Company & 254.9 & 28.3 & 98.5 & 11.0 & 84.4 & 9.4 & 16.2 & 1.8 & 312.5 & 34.7 & 34.1 & 3.8 & 900.0 & 90.0 \\
\hline Jarrow Formulas & 127.2 & 15.3 & 47.5 & 5.7 & 93.1 & 11.2 & 32.5 & 3.9 & 230.2 & 27.6 & 248.2 & 29.8 & 833.4 & 83.3 \\
\hline Mean & $170.8^{a}$ & $18.8^{a}$ & $65.9^{a}$ & $7.2^{\mathrm{a}}$ & $91.7^{\mathrm{a}}$ & $10.1^{a}$ & $22.6^{a}$ & $2.5^{\mathrm{a}}$ & $400.2^{a}$ & $43.8^{a}$ & $82.2^{a}$ & $9.3^{\mathrm{a}}$ & $908.5^{a}$ & $90.9^{a}$ \\
\hline SEM & 18.0 & 1.9 & 6.9 & 0.7 & 2.0 & 0.2 & 1.4 & 0.2 & 30.9 & 3.2 & 19.2 & 2.4 & 9.6 & 1.0 \\
\hline \multicolumn{15}{|c|}{ Powders $(n=5)$} \\
\hline Permixon & 96.7 & 29.5 & 38.5 & 11.8 & 30.5 & 9.3 & 5.6 & 1.7 & 111.7 & 34.1 & 11.5 & 3.5 & 327.3 & 32.7 \\
\hline Biochem & 40.7 & 17.1 & 16.2 & 6.8 & 58.2 & 24.4 & 47.0 & 19.7 & 36.4 & 15.3 & 19.1 & 8.0 & 238.3 & 23.8 \\
\hline Natures' Way & 38.0 & 26.5 & 14.3 & 10.0 & 18.2 & 12.7 & 14.4 & 10.0 & 40.1 & 27.9 & 6.5 & 4.5 & 143.6 & 14.4 \\
\hline Solaray & 40.5 & 33.7 & 14.8 & 12.3 & 11.9 & 9.9 & 2.5 & 2.1 & 34.2 & 28.5 & 6.1 & 5.1 & 120.1 & 12.0 \\
\hline GNC Saw Palmetto Formula & 14.6 & 21.3 & 5.6 & 8.2 & 15.2 & 22.1 & 9.6 & 13.9 & 14.6 & 21.2 & 4.6 & 6.7 & 68.6 & 6.9 \\
\hline Mean & $46.1^{b}$ & $25.6^{b}$ & $17.9^{b}$ & $9.8^{b}$ & $26.8^{b}$ & $15.7^{b}$ & $15.8^{b}$ & $9.5^{b}$ & $47.4^{b}$ & $25.4^{\mathrm{b}}$ & $9.6^{b}$ & $5.6^{\mathrm{a}}$ & $179.6^{b}$ & $18.0^{b}$ \\
\hline SEM & 9.0 & 2.0 & 3.7 & 0.7 & 5.7 & 2.1 & 5.4 & 2.3 & 11.1 & 2.2 & 1.8 & 0.5 & 30.7 & 3.1 \\
\hline \multicolumn{15}{|c|}{ Standard Reference Material } \\
\hline SRM 3251 & 259.9 & 26.3 & 10.6 & 10.6 & 86.6 & 8.5 & 16.9 & 1.7 & 331.1 & 34.6 & 50.2 & 6.0 & 983.6 & 98.4 \\
\hline
\end{tabular}

* \% of dry mass (weight/weight), different letters indicate significant differences $(p<0.05)$ between the four supplement categories in Tables 2 and 3. Samples and SRM from the same lot,

were extracted and analyzed in duplicate. 
Table 3. Fatty acid quantities ( $\mathrm{mg} / \mathrm{g})$ and composition (\% of total fatty acids) in dried berry and tincture saw palmetto supplements.

\begin{tabular}{|c|c|c|c|c|c|c|c|c|c|c|c|c|c|c|}
\hline \multirow[t]{2}{*}{ Supplement } & \multicolumn{2}{|c|}{$\begin{array}{l}\text { Laurate } \\
\text { (C12:0) }\end{array}$} & \multicolumn{2}{|c|}{$\begin{array}{l}\text { Myristate } \\
\text { (C14:0) }\end{array}$} & \multicolumn{2}{|c|}{$\begin{array}{l}\text { Palmitate } \\
\text { (C16:0) }\end{array}$} & \multicolumn{2}{|c|}{$\begin{array}{l}\text { Stearate } \\
\text { (C18:0) }\end{array}$} & \multicolumn{2}{|c|}{$\begin{array}{l}\text { Oleate } \\
\text { (C18:1) }\end{array}$} & \multicolumn{2}{|c|}{$\begin{array}{l}\text { Linoleate } \\
\text { (C18:2) }\end{array}$} & \multicolumn{2}{|c|}{$\begin{array}{l}\text { Total Fatty } \\
\text { Acid }\end{array}$} \\
\hline & $\mathrm{mg} / \mathrm{g}$ & $\%$ & $\mathrm{mg} / \mathrm{g}$ & $\%$ & $\mathbf{m g} / \mathrm{g}$ & $\%$ & $\mathrm{mg} / \mathrm{g}$ & $\%$ & $\mathrm{mg} / \mathrm{g}$ & $\%$ & $\mathrm{mg} / \mathrm{g}$ & $\%$ & $\mathrm{mg} / \mathrm{g}$ & $\% *$ \\
\hline \multicolumn{15}{|c|}{ Dried berries $(n=3)$} \\
\hline Mountain Rose Herbs (dried berries) & 41.7 & 31.1 & 15.1 & 11.3 & 12.4 & 9.3 & 2.6 & 1.9 & 41.2 & 30.8 & 6.6 & 4.9 & 134.0 & 13.4 \\
\hline $\begin{array}{c}\text { Mountain Rose Herbs } \\
\text { (powdered berries) }\end{array}$ & 37.1 & 28.6 & 15.6 & 12.0 & 12.6 & 9.7 & 2.1 & 1.7 & 43.9 & 33.9 & 4.8 & 3.7 & 129.7 & 13.0 \\
\hline More than Alive (powdered berries) & 37.5 & 32.5 & 14.1 & 12.2 & 11.5 & 9.9 & 2.2 & 1.9 & 34.6 & 30.0 & 5.6 & 4.9 & 115.7 & 11.6 \\
\hline Mean & $38.8^{\mathrm{b}}$ & $30.7^{b, c}$ & $14.9^{b}$ & $11.8^{\mathrm{b}}$ & $12.2^{\mathrm{c}}$ & $9.6^{\mathrm{a}}$ & $2.3^{\mathrm{c}}$ & $1.8^{\mathrm{a}}$ & $39.9^{b}$ & $31.5^{b}$ & $5.7^{\mathrm{b}}$ & $4.5^{\mathrm{a}}$ & $126.4^{b, c}$ & $12.6^{\mathrm{b}, \mathrm{c}}$ \\
\hline SEM & 0.9 & 0.7 & 0.3 & 0.2 & 0.2 & 0.1 & 0.1 & 0.1 & 1.7 & 0.8 & 0.3 & 0.3 & 3.5 & 0.3 \\
\hline \multicolumn{15}{|c|}{ Tinctures $(n=5)$} \\
\hline Oregon's Wild Harvest & 28.4 & 29.2 & 10.6 & 10.9 & 8.7 & 9.0 & 1.7 & 1.8 & 32.0 & 32.9 & 4.5 & 4.6 & 97.3 & 9.7 \\
\hline GAIA Herbs & 22.8 & 35.2 & 9.3 & 14.3 & 5.5 & 8.4 & 0.6 & 1.0 & 20.1 & 31.0 & 1.2 & 1.9 & 64.8 & 6.5 \\
\hline LA Naturals & 5.1 & 40.2 & 1.7 & 13.4 & 1.1 & 8.6 & 0.2 & 1.4 & 3.0 & 23.1 & 0.7 & 5.6 & 12.8 & 1.3 \\
\hline Teeter Creek & 3.7 & 36.5 & 1.2 & 11.6 & 0.7 & 7.4 & 0.1 & 1.3 & 2.4 & 23.6 & 0.3 & 2.7 & 10.1 & 1.0 \\
\hline Nature's Answer ** & 0.0 & 0.0 & 0.0 & 0.0 & 0.0 & 0.0 & 0.0 & 19.3 & 0.0 & 0.0 & 0.0 & 0.0 & 0.1 & 0.0 \\
\hline Mean & $15.0^{b}$ & $35.3^{c}$ & $5.7^{\mathrm{b}}$ & $12.5^{\mathrm{b}}$ & $4.0^{c}$ & $8.3^{\mathrm{a}}$ & $0.7^{\mathrm{c}}$ & $1.4^{\mathrm{a}}$ & $14.3^{b}$ & $27.6^{b}$ & $1.7^{\mathrm{c}}$ & $3.7^{\mathrm{a}}$ & $46.3^{c}$ & $4.6^{\mathrm{c}}$ \\
\hline SEM & 4.1 & 1.5 & 1.6 & 0.5 & 1.2 & 0.2 & 0.2 & 0.1 & 4.7 & 1.6 & 0.6 & 0.6 & 13.9 & 1.4 \\
\hline
\end{tabular}

* \% of dry mass (weight/weight), ** Nature's Answer was excluded from statistical analysis due to its negligible fatty acid content compared with other products. Different letters indicate

significant differences $(p<0.05)$ between the four supplement categories in Tables 2 and 3. Samples, and SRM from the same lot, were extracted and analyzed in duplicate. 


\subsection{Fatty Acid Quantities and Percentages within Supplement Categories}

Within supplement categories, fatty acid quantities and percentages across the three dried berry supplements were fairly consistent (Tables 2 and 3). Tinctures, on the other hand, varied widely, with total fatty acids ranging from 0.1 to $97.3 \mathrm{mg} / \mathrm{g}$. There was less variability in total fatty acids in liquids (710.3-941.3 mg/g) and powder (68.6-327.3 mg/g) supplements; however, there were some notable trends. Among liquid supplements, Doctor's Best and Saw Palmetto Harvesting Company contained higher laurate and myristate and lower oleate quantities. Jarrow Formulas contained much higher quantities of linoleate than the other liquid supplements. Among powder supplements, Biochem contained lower quantities of laurate and myristate levels but higher quantities of stearate and oleate.

\subsection{Phytosterol Quantities and Percentages between Supplement Categories}

Phytosterol quantities and percentages in SRM, liquid, powder, dried berry, and tincture saw palmetto supplements are shown in Tables 4 and 5 . Jarrow formulas $(8.33 \mathrm{mg} / \mathrm{g}$ ) and Biochem $(22.80 \mathrm{mg} / \mathrm{g})$ were not included in category means and were excluded from statistical analysis due to very high phytosterol content compared with the other supplements. $\beta$-Sitosterol was the predominant phytosterol $(47.32 \%-79.48 \%)$ in all saw palmetto supplements. Liquid supplements contained significantly higher total $(2.04 \mathrm{mg} / \mathrm{g})$ and individual phytosterol quantities than powders, dried berry, and tincture supplements. Liquid supplements also contained a significantly higher percentage of $\beta$-sitosterol than the other supplement categories and a lower percentage of campesterol compared with powders and dried berry supplements. The total phytosterol content of powders $(0.42 \mathrm{mg} / \mathrm{g})$ and dried berries were similar, but powder supplements $(0.33 \mathrm{mg} / \mathrm{g})$ contained significantly higher phytosterol quantities than tincture supplements $(0.10 \mathrm{mg} / \mathrm{g})$. Dried berries also contained significantly higher stigmasterol quantities than tincture supplements. Dried berry supplements contained a significantly higher and lower percentage, respectively, of campesterol and $\beta$-sitosterol than the other supplement categories. Dried berry and tincture supplements also contained significantly higher percentages of stigmasterol than liquid and powder supplements.

\subsection{Phytosterol Quantities and Percentages within Supplement Categories}

Liquid and powder supplements had similar quantities of individual and total phytosterols, with the exception of Jarrow Formulas and Biochem, which contained much higher phytosterol quantities (Tables 4 and 5). Dried berry supplements had similar quantities and percentages of individual and total phytosterols. All tincture supplements contained low phytosterols quantities.

\subsection{Difference between Stated and Measured Total Fatty Acid Content}

Stated total fatty acid content from supplement labels was only available for liquid supplements. These stated quantities are compared to measured content in Table 6. Measured total fatty acid content in five out of six liquid supplements was greater than or equal to the quantities stated on their labels. It is worth noting that one supplement whose measured content $(833 \mathrm{mg} / \mathrm{g})$ was below its stated amount, Jarrow Formulas, was only 7\% lower than its stated content $(850-950 \mathrm{mg} / \mathrm{g})$. 
Table 4. Phytosterol quantities $(\mathrm{mg} / \mathrm{g})$ and composition (\% of total phytosterols) in SRM, liquid and powder saw palmetto supplements.

\begin{tabular}{|c|c|c|c|c|c|c|c|c|}
\hline \multirow[t]{2}{*}{ Supplement } & \multicolumn{2}{|c|}{ Campesterol } & \multicolumn{2}{|c|}{ Stigmasterol } & \multicolumn{2}{|c|}{$\beta$-sitosterol } & \multicolumn{2}{|c|}{ Total Phytosterols } \\
\hline & $\mathbf{m g} / \mathbf{g}$ & $\%$ & $\mathrm{mg} / \mathrm{g}$ & $\%$ & $\mathrm{mg} / \mathrm{g}$ & $\%$ & $\mathrm{mg} / \mathrm{g}$ & $\% *$ \\
\hline \multicolumn{9}{|c|}{ Liquids } \\
\hline Jarrow Formulas ** & 8.33 & 29.09 & 4.01 & 14.03 & 16.29 & 56.88 & 28.63 & 2.86 \\
\hline Doctor's Best & 0.54 & 19.21 & 0.24 & 8.53 & 2.04 & 72.26 & 2.83 & 0.28 \\
\hline Now Foods & 0.29 & 12.56 & 0.13 & 5.66 & 1.92 & 81.78 & 2.35 & 0.23 \\
\hline Saw Palmetto Harvesting Company & 0.34 & 21.05 & 0.16 & 10.09 & 1.12 & 68.86 & 1.62 & 0.16 \\
\hline Solaray & 0.23 & 11.10 & 0.11 & 5.19 & 1.73 & 83.71 & 2.07 & 0.21 \\
\hline Spring Valley Natural Foods & 0.15 & 7.20 & 0.11 & 5.52 & 1.80 & 87.28 & 2.06 & 0.21 \\
\hline GNC Herbal Plus & 0.15 & 11.61 & 0.07 & 5.40 & 1.08 & 82.99 & 1.31 & 0.13 \\
\hline Mean & $0.28^{\mathrm{a}}$ & $13.79^{\mathrm{a}}$ & $0.14^{\mathrm{a}}$ & $6.73^{\mathrm{a}}$ & $1.62^{\mathrm{a}}$ & $79.48^{\mathrm{a}}$ & $2.04^{\mathrm{a}}$ & $0.20^{\mathrm{a}}$ \\
\hline SEM & 0.04 & 1.45 & 0.02 & 0.57 & 0.12 & 1.99 & 0.15 & 0.02 \\
\hline \multicolumn{9}{|c|}{ Powders } \\
\hline Biochem ** & 22.80 & 30.30 & 19.75 & 26.55 & 32.55 & 43.15 & 75.11 & 7.51 \\
\hline Permixon & 0.18 & 21.06 & 0.06 & 7.68 & 0.60 & 71.27 & 0.84 & 0.08 \\
\hline Nature's Way & 0.10 & 24.65 & 0.04 & 11.11 & 0.25 & 64.24 & 0.39 & 0.04 \\
\hline Solaray & 0.07 & 23.89 & 0.03 & 9.30 & 0.20 & 66.80 & 0.30 & 0.03 \\
\hline GNC Saw Palmetto Formula & 0.03 & 19.83 & 0.01 & 9.19 & 0.10 & 70.98 & 0.15 & 0.01 \\
\hline Mean & $0.09^{b}$ & $22.36^{\mathrm{b}}$ & $0.04^{\mathrm{b}, \mathrm{c}}$ & $9.32^{\mathrm{a}}$ & $0.29^{b}$ & $68.32^{\mathrm{b}}$ & $0.42^{b}$ & $0.04^{\mathrm{b}}$ \\
\hline SEM & 0.02 & 0.90 & 0.01 & 0.53 & 0.07 & 1.33 & 0.10 & 0.01 \\
\hline \multicolumn{9}{|c|}{ Standard Reference Material } \\
\hline SRM 3251 & 0.41 & 19.69 & 0.18 & 8.57 & 1.48 & 71.74 & 2.06 & 0.21 \\
\hline
\end{tabular}

* \% dry mass (weight/weight), ** Jarrow Formulas and Biochem were excluded from statistical analysis due to their very high phytosterol content compared with other supplements. Different letters indicate significant differences $(p<0.05)$ between the four supplement categories in Tables 4 and 5 . Samples, and SRM from the same lot, were extracted and analyzed in duplicate. 
Table 5. Phytosterol quantities $(\mathrm{mg} / \mathrm{g})$ and composition (\% of total phytosterols) in dried berry and tincture saw palmetto supplements.

\begin{tabular}{|c|c|c|c|c|c|c|c|c|}
\hline \multirow[t]{2}{*}{ Supplement } & \multicolumn{2}{|c|}{ Campesterol } & \multicolumn{2}{|c|}{ Stigmasterol } & \multicolumn{2}{|c|}{$\beta$-sitosterol } & \multicolumn{2}{|c|}{ Total Sterols } \\
\hline & $\mathrm{mg} / \mathrm{g}$ & $\%$ & $\mathrm{mg} / \mathrm{g}$ & $\%$ & $\mathrm{mg} / \mathrm{g}$ & $\%$ & $\mathbf{m g} / \mathrm{g}$ & $\% *$ \\
\hline \multicolumn{9}{|c|}{ Dried berries } \\
\hline Mountain Rose Herbs (dried berries) & 0.16 & 41.45 & 0.09 & 21.91 & 0.13 & 36.64 & 0.38 & 0.04 \\
\hline Mountain Rose Herbs (powdered berries) & 0.09 & 27.93 & 0.06 & 17.41 & 0.17 & 54.66 & 0.32 & 0.03 \\
\hline More Than Alive (powdered berries) & 0.08 & 27.28 & 0.07 & 22.06 & 0.15 & 50.66 & 0.30 & 0.03 \\
\hline Mean & $0.11^{\mathrm{b}}$ & $32.22^{\mathrm{c}}$ & $0.07^{\mathrm{b}}$ & $20.46^{\mathrm{b}}$ & $0.15^{b}$ & $47.32^{\mathrm{c}}$ & $0.33^{b, c}$ & $0.03^{b}$ \\
\hline SEM & 0.02 & 3.30 & 0.01 & 2.86 & 0.01 & 5.16 & 0.03 & 0.00 \\
\hline \multicolumn{9}{|c|}{ Tinctures } \\
\hline Oregon's Wild Harvest & 0.04 & 16.40 & 0.02 & 9.16 & 0.18 & 74.45 & 0.24 & 0.02 \\
\hline GAIA Herbs & 0.03 & 17.95 & 0.02 & 11.65 & 0.11 & 70.40 & 0.16 & 0.02 \\
\hline LA Naturals Saw Palmetto drops & 0.01 & 16.73 & 0.01 & 13.72 & 0.04 & 69.55 & 0.06 & 0.01 \\
\hline Nature's Answer & 0.00 & 21.12 & 0.00 & 25.23 & 0.01 & 53.65 & 0.02 & 0.00 \\
\hline Teeter Creek & 0.01 & 22.27 & 0.00 & 14.71 & 0.02 & 63.02 & 0.02 & 0.00 \\
\hline Mean & $0.02^{b}$ & $18.89^{\mathrm{a}, \mathrm{b}}$ & $0.01^{\mathrm{c}}$ & $14.89^{b}$ & $0.07^{\mathrm{b}}$ & $66.21^{\mathrm{b}}$ & $0.10^{\mathrm{c}}$ & $0.01^{\mathrm{b}}$ \\
\hline SEM & 0.00 & 0.83 & 0.00 & 1.86 & 0.02 & 2.47 & 0.03 & 0.00 \\
\hline
\end{tabular}

* \% of dry mass (weight/weight), different letters indicate significant differences $(p<0.05)$ between the four supplement categories in Tables 4 and 5 . Samples, and SRM from the same lot, were extracted and analyzed in duplicate. 
Table 6. Stated, measured, and percentage difference in total fatty acid content in liquid saw palmetto supplements.

\begin{tabular}{cccc}
\hline Product Name & $\begin{array}{c}\text { Stated Content } \\
(\mathbf{m g} / \mathbf{g})\end{array}$ & $\begin{array}{c}\text { Measured Content } \\
(\mathbf{m g} / \mathbf{g})\end{array}$ & \% Difference \\
\hline Doctor's Best & 900 & 941 & +5 \\
GNC Herbal Plus & 850 & 934 & +10 \\
Spring Valley Natural Foods & $850-950$ & 923 & +3 \\
Now Foods & $850-950$ & 915 & +2 \\
Solaray & 850 & 913 & +7 \\
Jarrow Formulas & $850-950$ & 833 & -7 \\
\hline
\end{tabular}

\section{Discussion}

We found great variability in total and individual fatty acid and phytosterol quantities and percentages in 20 commercial saw palmetto supplements. There was also a great deal of variability in the total and individual fatty acid and phytosterol quantities and percentages between the four different saw palmetto supplement categories. We believe we are the first to collect and analyze samples from these different supplement categories. Overall, we found that liquid supplements contained the highest fatty acid and phytosterol quantities, followed by powder, dried berry, and tincture supplements.

Fatty acid and phytosterol contents have been reported previously for SRM 3251 [20]. Because total fatty acid quantities were not reported, we multiplied the reported free fatty acid composition by the triglyceride to free fatty acid ratio. Our measured total fatty acid and total phytosterol contents (908.5 mg/g, $2.0 \mathrm{mg} / \mathrm{g}$ ) are comparable with the calculated SRM 3251 values (983.6 mg/g, $2.4 \mathrm{mg} / \mathrm{g}$ ) [20]. These results support that our extraction and analysis procedures were accurate in measuring these components. The total fatty acid percentages of liquid samples $(83.3 \%-94.1 \%)$ are consistent with the values reported for hexane (98.7\%-99.7\%) [41], supercritical $\mathrm{CO}_{2}(96.1 \%-97.4 \%)$ [42], $\mathrm{CO}_{2}(92.2 \%)$ [43], ethanol (88.7\%) [43] and lipid (92.5\%) [15] saw palmetto extracts. The total fatty acid percentages are also consistent with the sum of the free fatty acids, esters, and glycerides $(87.0 \%-95.3 \%)$ in 14 European saw palmetto extracts [40]. However, the total fatty acid percentages are higher than those reported for a saw palmetto ethanol extract (68.7\%) [43].

Dried berry supplements contained $11.6 \%-13.4 \%$ fatty acids, which is similar to the levels reported in SRM 3250 ( 15.8\%), a saw palmetto berry, when calculated as described above [20]. Permixon, one of the powder supplements, has been analyzed previously and reported to contain $91.4 \%$ free fatty acids, esters, and glycerides [40]. This was far higher than the $32.7 \%$ fatty acid content that we measured. Our method may not extract fatty acids efficiently from powder samples and could be underestimating the fatty acid content. To the best of our knowledge, we are the first to measure tincture saw palmetto supplements. The levels of the major phytosterols (campesterol, stigamasterol, and $\beta$-sitosterol) in the saw palmetto supplements is consistent with quantities found in a variety of previously analyzed saw palmetto supplements [44] and is similar to the $\beta$-sitosterol content in a supercritical $\mathrm{CO}_{2}$ saw palmetto extract [42].

Ingredients added to saw palmetto supplements (Table 1) help explain the differences we found in fatty acid and phytosterol quantities and percentages. Most liquid, and a few powder, supplements contain added ingredients. For instance, among liquid supplements, only Doctor's Best and Saw 
Palmetto Harvesting Company had no or a limited number of extra ingredients added to them. This probably explains why they have much higher laurate and myristate quantities. Jarrow Formulas, on the other hand, has a pumpkin seed oil base that is enriched in phytosterols, which explains its high linoleate and phytosterol quantities. The remaining four liquid supplements contained either olive oil or extra virgin olive oil (GNC Herbal Plus, Spring Valley Natural Foods, Now Foods, Solaray) which explains their higher oleate percentages compared to other liquid supplements. The powder supplements Nature's Way and Biochem contain magnesium stearate, which explains their high quantities of stearate. Biochem also contains pygeum root extract, which is probably the reason why the supplement contains very high quantities of phytosterols [50].

Industrial preparative extraction methods may also help explain the differences in fatty acid and phytosterol quantities in the supplements. Saw palmetto supplements are usually extracted using solvents like hexane, ethyl alcohol, or supercritical $\mathrm{CO}_{2}$. All the tinctures were alcohol-extracted, but among liquid and powder supplements, only Doctor's Best and Jarrow Formulas, which were extracted using supercritical $\mathrm{CO}_{2}$, stated how they were extracted. Thus, the unknown methods used to produce the supplements prevent us from understanding how extraction affects supplement fatty acid and phytosterol content. Other factors that might also contribute to the observed variation are batch differences and plant growing conditions.

We found that $83 \%$ of the liquid supplements contained greater than or equal to their stated fatty acid content. This is higher than the $33 \%$ of the measured saw palmetto supplements analyzed in a previous study [39]. Supplement companies that state their fatty acid content may be employing better manufacturing procedures and analyzing their products to ensure they contain the stated values.

\section{Implications}

Our findings suggest that liquid saw palmetto supplements are the best choice for individuals who want to take a saw palmetto supplement that has the highest concentration of both fatty acids and phytosterols. However, further research is needed to determine whether these supplements are indeed more efficacious.

\section{Conclusions}

We believe we are the first to characterize both fatty acid and phytosterol content of commercial saw palmetto supplements. We plan to determine the anti-androgen action of saw palmetto supplements with different nutrient profiles hoping that the understanding gained will explain the varied response to saw palmetto supplements seen in previous studies.

\section{Conflicts of Interest}

The authors declare no conflict of interest.

\section{Acknowledgments}

This is contribution number 13-371-J from the Kansas Agricultural Experiment Station. 


\section{References}

1. Barnes, P.M.; Bloom, B.; Nahin, R.L. Complementary and Alternative Medicine Use among Adults and Children: United States, 2007; CDC National Health Statistics Report: Hyattsville, MD, USA, December 2008; pp. 1-23.

2. Blumenthal, M.; Lindstrom, A.; Ooyen, C.; Lynch, M.E. Herb supplement sales increase $4.5 \%$ in 2011, despite still-weak economy, herb sales continue multi-year growth. HerbalGram 2012, 95, 60-64.

3. Bishop, F.L.; Rea, A.; Lewith, H.; Chan, Y.K.; Saville, J.; Prescott, P.; von Elm, E.; Lewith, G.T. Complementary medicine use by men with prostate cancer: A systematic review of prevalence studies. Prostate Cancer Prostatic Dis. 2011, 14, 1-13.

4. Bauer, C.; Ishak, M.; Johnson, E.; Beebe Dimmer, J.; Cooney, K. Prevalence and correlates of vitamin and supplement usage among men with a family history of prostate cancer. Integr. Cancer Ther. 2012, 11, 83-89.

5. Iehlé, C.; Délos, S.; Guirou, O.; Tate, R.; Raynaud, J.P.; Martin, P.M. Human prostatic steroid $5 \alpha$-reductase isoforms-A comparative study of selective inhibitors. J. Steroid Biochem. Mol. Biol. 1995, 54, 273-279.

6. Bayne, C.W.; Donnelly, F.; Ross, M.; Habib, F.K. Serenoa repens (Permixon): A $5 \alpha$-reductase types I and II inhibitor-New evidence in a coculture model of BPH. Prostate 1999, 40, 232-241.

7. Bayne, C.W.; Ross, M.; Donnelly, F.; Habib, F.K. The selectivity and specificity of the actions of the lipido-sterolic extract of Serenoa repens (Permixon) on the prostate. J. Urol. 2000, 164, 876-881.

8. Habib, F.K.; Ross, M.; Ho, C.K.H.; Lyons, V.; Chapman, K. Serenoa repens (permixon) inhibits the $5 \alpha$-reductase activity of human prostate cancer cell lines without interfering with PSA expression. Int. J. Cancer 2005, 114, 190-194.

9. Anderson, M.L. A preliminary investigation of the enzymatic inhibition of $5 \alpha$-reduction and growth of prostatic carcinoma cell line LNCap-FGC by natural astaxanthin and Saw Palmetto lipid extract in vitro. J. Herbal Pharmacother. 2005, 5, 17-26.

10. Pais, P. Potency of a novel saw palmetto ethanol extract, SPET-085, for inhibition of $5 \alpha$-reductase II. Adv. Ther. 2010, 27, 555-563.

11. Van Coppenolle, F.; Le Bourhis, X.; Carpentier, F.; Delaby, G.; Cousse, H.; Raynaud, J.P.; Dupouy, J.P.; Prevarskaya, N. Pharmacological effects of the lipidosterolic extract of Serenoa repens (Permixon) on rat prostate hyperplasia induced by hyperprolactinemia: Comparison with finasteride. Prostate 2000, 43, 49-58.

12. Talpur, N.; Echard, B.; Bagchi, D.; Bagchi, M.; Preuss, H.G. Comparison of Saw Palmetto (extract and whole berry) and Cernitin on prostate growth in rats. Mol. Cell. Biochem. 2003, 250, 21-26.

13. Carbajal, D.; Molina, V.; Mas, R.; Arruzazabala, M.L. Therapeutic effect of D-004, a lipid extract from Roystonea regia fruits, on prostate hyperplasia induced in rats. Drugs Exp. Clin. Res. 2005, 31, 193-197.

14. Wadsworth, T.L.; Worstell, T.R.; Greenberg, N.M.; Roselli, C.E. Effects of dietary saw palmetto on the prostate of transgenic adenocarcinoma of the mouse prostate model (TRAMP). Prostate 2007, 67, 661-673. 
15. Arruzazabala, M.L.; Molina, V.; Mas, R.; Carbajal, D.; Marrero, D.; González, V.; Más, R.; Rodríguez, E. Effects of coconut oil on testosterone-induced prostatic hyperplasia in Sprague-Dawley rats. J. Pharm. Pharmacol. 2007, 59, 995-999.

16. Rhodes, L.; Primka, R.L.; Berman, C.; Vergult, G.; Gabriel, M.; Pierre-Malice, M.; Gibelin, B. Comparison of finasteride (Proscar), a $5 \alpha$-reductase inhibitor, and various commercial plant extracts in in vitro and in vivo 5a-reductase inhibition. Prostate 1993, 22, 43-51.

17. Hill, B.; Kyprianou, N. Effect of permixon on human prostate cell growth: Lack of apoptotic action. Prostate 2004, 61, 73-80.

18. Strauch, G.; Perles, P.; Vergult, G.; Gabriel, M.; Gibelin, B.; Cummings, S.; Malbecq, W.; Malice, M.P. Comparison of finasteride (Proscar) and Serenoa repens (Permixon) in the inhibition of $5 \alpha$-reductase in healthy male volunteers. Eur. Urol. 1994, 26, 247-252.

19. U.S. Department of Agriculture, Agricultural Research Service USDA National Nutrient Database for Standard Reference, Release 25. Available online: http://ndb.nal.usda.gov/ (accessed on 28 May 2013).

20. Schantz, M.M.; Bedner, M.; Long, S.E.; Molloy, J.L.; Murphy, K.E.; Porter, B.J.; Putzbach, K.; Rimmer, C.A.; Sander, L.C.; Sharpless, K.E.; et al. Development of saw palmetto (Serenoa repens) fruit and extract standard reference materials. Anal. Bioanal. Chem. 2008, 392, 427-438.

21. Liang, T.; Liao, S. Growth suppression of hamster flank organs by topical application of gamma-linolenic and other fatty acid inhibitors of 5a-reductase. J. Investig. Dermatol. 1997, 109, $152-157$.

22. Weisser, H.; Tunn, S.; Behnke, B.; Krieg, M. Effects of the sabal serrulata extract IDS 89 and its subfractions on $5 \alpha$-reductase activity in human benign prostatic hyperplasia. Prostate 1996, 28, 300-306.

23. Niederprum, H.J.; Schweikert, H.U.; Thuroff, J.W.; Zanker, K.S. Inhibition of steroid $5 \alpha$-reductase activity by aliphatic fatty acids. Candidates for chemoprevention of prostate cancer. Ann. N. Y. Acad. Sci. 1995, 768, 227-230.

24. Raynaud, J.; Cousse, H.; Martin, P. Inhibition of type 1 and type $25 \alpha$-reductase activity by free fatty acids, active ingredients of Permixon. J. Steroid Biochem. Mol. Biol. 2002, 82, 233-239.

25. Abe, M.; Ito, Y.; Suzuki, A.; Onoue, S.; Noguchi, H.; Yamada, S. Isolation and pharmacological characterization of fatty acids from saw palmetto extract. Anal. Sci. 2009, 25, 553-557.

26. Abe, M.; Ito, Y.; Yunzul, L.; Oki Fujino, T.; Yamada, S.; Oyunzul, L. Pharmacologically relevant receptor binding characteristics and $5 \alpha$-reductase inhibitory activity of free fatty acids contained in saw palmetto extract. Biol. Pharm. Bull. 2009, 32, 646-650.

27. Berges, R.R.; Windeler, J.; Senge, T.; Aeikens, B.; Trampisch, H.J.; $\beta$-Sitosterol Study Group. Randomised, placebo-controlled, double-blind clinical trial of $\beta$-sitosterol in patients with benign prostatic hyperplasia. Lancet 1995, 345, 1529-1532.

28. Von Holtz, R.L.; Fink, C.S.; Awad, A.B. $\beta$-Sitosterol activates the sphingomyelin cycle and induces apoptosis in LNCaP human prostate cancer cells. Nutr. Cancer 1998, 32, 8-12.

29. Awad, A.B.; Williams, H.; Kim, U.; Fink, C.S. In vitro and in vivo (SCID mice) effects of phytosterols on the growth and dissemination of human prostate cancer PC-3 cells. Eur. J. Cancer Prev. 2001, 10, 507-513. 
30. Cabeza, M.; Bratoeff, E.; Heuze, I.; Ramirez, E.; Sanchez, M.; Rami-rez, E.; Sanchez, M.; Flores, E. Effect of $\beta$-sitosterol as inhibitor of $5 \alpha$-reductase in hamster prostate. Proc. West. Pharmacol. Soc. 2003, 46, 153-155.

31. Scholtysek, C.; Krukiewicz, A.; Alonso, J.; Sharma, K.; Sharma, P.; Goldmann, W. Characterizing components of the Saw Palmetto Berry Extract (SPBE) on prostate cancer cell growth and traction. Biochem. Biophys. Res. Commun. 2009, 379, 795-798.

32. Weihrauch, J.L.; Gardner, J.M. Sterol content of foods of plant origin. J. Am. Diet. Assoc. 1978, 73, 39-47.

33. Bent, S.; Kane, C.; Shinohara, K.; Neuhaus, J.; Hudes, E.; Goldberg, H.; Avins, A. Saw palmetto for benign prostatic hyperplasia. N. Engl. J. Med. 2006, 354, 557-566.

34. Barry, M.; Meleth, S.; Lee, J.; Kreder, K.; Avins, A.; Nickel, J.C.; Roehrborn, C.; Crawford, E.D.; Foster, H.; Kaplan, S.; et al. Effect of increasing doses of saw palmetto extract on lower urinary tract symptoms: A randomized trial. J. Am. Med. Assoc. 2011, 306, 1344-1351.

35. MacDonald, R.; Tacklind, J.; Rutks, I.; Wilt, T. Serenoa repens monotherapy for benign prostatic hyperplasia (BPH): An updated Cochrane systematic review. BJU Int. 2012, 109, 1756-1761.

36. Scaglione, F.; Lucini, V.; Pannacci, M.; Caronno, A.; Leone, C. Comparison of the potency of different brands of Serenoa repens extract on $5 \alpha$-reductase types I and II in prostatic co-cultured epithelial and fibroblast cells. Pharmacology 2008, 82, 270-275.

37. Scaglione, F.; Lucini, V.; Pannacci, M.; Dugnani, S.; Leone, C. Comparison of the potency of 10 different brands of Serenoa repens extracts. Eur. Rev. Med. Pharmacol. Sci. 2012, 16, 569-574.

38. Wolsko, P.M.; Solondz, D.K.; Phillips, R.S.; Schachter, S.C.; Eisenberg, D.M. Lack of herbal supplement characterization in published randomized controlled trials. Am. J. Med. 2005, 118, 1087-1093.

39. Feifer, A.H.; Fleshner, N.E.; Klotz, L. Analytical accuracy and reliability of commonly used nutritional supplements in prostate disease. J. Urol. 2002, 168, 150-154.

40. Habib, F.K.; Wyllie, M.G. Not all brands are created equal: A comparison of selected components of different brands of Serenoa repens extract. Prostate Cancer Prostatic Dis. 2004, 7, 195-200.

41. Priestap, H.; Houle, P.; Bennett, B. Fatty acid composition of fruits of two forms of Serenoa repens. Chem. Nat. Compd. 2011, 47, 511-514.

42. Catchpole, O.J.; Perry, N.B.; da Silva, B.M.T.; Grey, J.B.; Smallfield, B.M. Supercritical extraction of herbs I: Saw Palmetto, St John's Wort, Kava Root, and Echinacea. J. Supercrit. Fluids 2002, 22, 129-138.

43. Ganzera, M.; Croom, E.M.; Khan, I.A. Determination of the Fatty Acid content of pumpkin seed, pygeum, and saw palmetto. J. Med. Food 1999, 2, 21-27.

44. Sorenson, W.R.; Sullivan, D. Determination of campesterol, stigmasterol, and $\beta$-sitosterol in saw palmetto raw materials and dietary supplements by gas chromatography: Collaborative study. J. AOAC Int. 2007, 90, 670-678.

45. Sorenson, W.R.; Sullivan, D. Determination of campesterol, stigmasterol, and $\beta$-sitosterol in saw palmetto raw materials and dietary supplements by gas chromatography: Single-laboratory validation. J. AOAC Int. 2006, 89, 22-34.

46. Sukhija, P.; Palmquist, D.L. Rapid method for determination of total fatty acid content and composition of feedstuffs and feces. J. Agric. Food Chem. 1988, 36, 1202-1206. 
47. Hawkins, A.; Yuan, K.; Armendariz, C.K.; Highland, G.; Bello, N.M.; Winowiski, T.; Drouillard, J.S.; Titgemeyer, E.C.; Bradford, B.J. Effects of urea formaldehyde condensation polymer treatment of flaxseed on ruminal digestion and lactation in dairy cows. J. Dairy Sci. 2013, 96, 3907-3915.

48. Zhang, X.; Julien-David, D.; Miesch, M.; Geoffroy, P.; Raul, F.; Roussi, S.; Aoudé-Werner, D.; Marchioni, E. Identification and quantitative analysis of $\beta$-sitosterol oxides in vegetable oils by capillary gas chromatography-mass spectrometry. Steroids 2005, 70, 896-906.

49. Merath, K.M.; Chang, B.; Dubielzig, R.; Jeannotte, R.; Sidjanin, D.J. A spontaneous mutation in Srebf2 leads to cataracts and persistent skin wounds in the lens opacity 13 (lop13) mouse. Mamm. Genome 2011, 22, 661-673.

50. Kadu, C.A.C.; Parich, A.; Schueler, S.; Konrad, H.; Muluvi, G.; Eyog-Matig, O.; Muchugi, A.; Williams, V.; Ramamonjisoa, L.; Kapinga, C.; et al. Bioactive constituents in Prunus africana: Geographical variation throughout Africa and associations with environmental and genetic parameters. Phytochemistry 2012, 83, 70-78.

(C) 2013 by the authors; licensee MDPI, Basel, Switzerland. This article is an open access article distributed under the terms and conditions of the Creative Commons Attribution license (http://creativecommons.org/licenses/by/3.0/). 